\title{
Radiové intervence Tetsua Kogawy: hudebnost pirátského mikrovysílání
}

\section{Radio Interventions of Tetsuo Kogawa: Musicality of Pirate Microtransmission}

Jan Sůsa / ok1gsb@seznam.cz

Social Sciences and Philosophy Department, Faculty of Education, Charles University, Prague, CZ

\begin{abstract}
The main topic of this paper is the radio art of Japanese artist and theoretician Tetsuo Kogawa. Kogawa's use of miniature VHF FM transmitters, with range just about few hundred meters, created an idiosyncratic alternative to mainstream radio broadcasting. After the mass expansion of the Internet, Japanese scene of pirate microtransmitters nearly disappeared. Can similar activity make sense even today?
\end{abstract}

\section{Keywords}

radio art, sound art, Tetsuo Kogawa, interdisciplinarity, DIY, performance 


\section{Rozhlas jako odcizující médium?}

Záměrem následujícího příspěvku je krátce představit tvorbu a teorii japonského umělce Tetsua Kogawy, jehož radiové intervence protínají oblast zvukového umění a politického aktivismu. Lze pomocí radiových vln proniknout do veřejného prostoru? Je rozhlas spojen s konkrétním „znějícím místem“ nebo jde o univerzální médium, které je nezávislé na daném prostoru? Existuje něco jako specifická hudebnost rozhlasu, nebo jde v tomto ohledu o neutrální medium, které pouze přenáší určité zvuky, bez toho aby je přetvářelo? Účelem následujícího textu rozhodně není na tyto otázky dát definitivní odpověd', ale spíše se pokusit je promyslet společně s několika texty Tetsua Kogawy, který kreativně pracuje s fenoménem radiových vln pomocí miniaturních vysílačů i v praktické rovině. Abychom přiblížili jeho uchopení fenoménu radiových vln, je třeba se alespoň krátce zmínit o kontextu, v kterém Kogawa svou svéráznou koncepci „mikrovysílání“ rozvinul.

Rádiové vlny pro Kogawu netvoří pouhý neutrální materiál k umělecké tvorbě, ale ze své podstaty mají mnohem širší politický potenciál. V textu Radio in the Chiasme upozorňuje, nakolik arbitrární je rozdělení „rádia“, které na jedné straně uvažujeme jako médium („rozhlas“) a na straně druhé jako fyzikální fenomén, projevující se chováním elektromagnetických vln („radiové vlny“). ${ }^{1}$ Rádiové vysílání ale v tomto smyslu tvoří nerozdělitelný komplex a přenos informace je závislý na chování př́rody. Informace se prolíná s šumem a její předání je závislé na často nepředvídatelných podmínkách šírení. Vzájemná komunikace je však v případě rozhlasového vysílání často jednostranná a v tradičních formátech jde téměř vždy pouze o jednosměrný přenos informací od producentů ke konzumentům.

Kogawovy rádiové aktivity, ústící ve specifické zvukové umění, je třeba vnímat společně s proměnami japonské společnosti v druhé polovině 20. století. Kogawa v této souvislosti upozorňuje na fakt, že ačkoli v japonské společnosti nikdy neproběhla buržoazní revoluce spojená s nabytím individuální svobody, přesto technologický vývoj přináší čím dál tím silnější „elektronický individualismus“, který od 60. let výrazně proniká i do rozmanitých oblastí soukromého života. ${ }^{2} \mathrm{~V}$ textu Beyond Electronic Individualism Kogawa analyzuje rychlé přijetí „amerického“ způsobu života, který se mj. dotýká i způsobu poslechu hudby, a to zejména v případě přenosných hudebních přehrávačů, využitelných též k poslechu rozhlasu. ${ }^{3}$ Zřejmě nejznámější přenosný kazetový přehrávač Walkman uvedla společnost Sony na trh v roce 1979 a způsobila značnou revoluci ve způsobu poslouchání hudby. Osobní přehrávač umožňuje takřka jakékoli veřejné místo využít pro soukromý poslech hudby. Elektronický individualismus se v tomto případě spojuje se

1 KOGAWA, Tetsuo. Radio in the Chiasme. In Re-Inventing Radio Aspects of Radio as Art. Heidi Grundmann - Elisabeth Zimmerman - Reinhard Braun et al. (eds.). Frankfurt am Main: Revolver, 2008 , s. $407-409$. [cit. 2017-08-31]. Dostupné z: http://anarchy.translocal.jp/non-japanese/radiointhechiasme.html.

2 KOGAWA, Tetsuo. Beyond electronic individualism. Canadian Journal of Political and Social Theory/ Revue Canadienne de Thetorie Politique et Sociale. 1984, roč. 8, č. 3. [cit. 2017-08-31]. Dostupné z: http:// anarchy.translocal.jp/non-japanese/electro.html.

3 Ibid. 
šetrností, důraz na osobní estetický požitek se prolíná se snahou nenarušovat soukromý prostor druhých. Společně s tím se zásadně mění i způsob poslouchání hudby, potažmo rozhlasu. „Nové“ způsoby poslechu hudby pomocí různých technologií, nevyžadujících fyzickou prrítomnost interpretů, lze kritizovat jako výrazně odcizující zkušenost. Zástupcem podobné kritiky, a to zejména v př́padě rozhlasového poslechu hudby, je Theodor Adorno, který společně s Maxem Horkheimerem analyzoval fenomén rozhlasu jako „autoritářskou" technologii, vedoucí ke standardizaci hudebního provozu a rozmělnění estetického zážitku z hudby: ${ }^{4}$

„Telefon ještě liberálně umožňoval, aby účastnik hrál roli subjektu. Rozhlas demokraticky čini ze všech stejnou měrou posluchače, aby je autoritářsky vydal v̌̌anc stejným programům různých stanic. Neni vyvinuta žádná aparatura umožňujici repliky, soukromá vysiláni se konaji nesvobodně. Omezuji se na apokryfni oblast , amatéru’', kteř́ jsou navic ještě organizováni shora. “5

Kogawa se ale vyhýbá odsouzení rozhlasu jako takového, jakkoli pro Adornovu negativní kritiku nalézá porozumění, ${ }^{6}$ a snaží se v rozhlasu nacházet nevyčerpaný potenciál, který je překrytý autoritářským rozlišením mezi producenty a konzumenty, či vysílajícími a poslouchajícími. Odcizení a uzavírání tradičního rozhlasového formátu, který jasně vymezuje binární role mezi producenty a konzumenty, vedlo Kogawu k uvažování o počátcích radiového vysílání. První experimentátoři fakticky nerozlišovali mezi př́ijmem a vysíláním - experimentování s oběma oblastmi bylo samozřejmé. Teprve postupně se vyvinulo prostředí, kdy se začalo považovat za přirozené, že radioamatéři experimentují nejprve s př́ijmem, a teprve po zvládnutí základních dovedností a vykonání zkoušek na telekomunikačním úřadu mohou vůbec uvažovat o vysílání. ${ }^{7}$

Bez většího přehánění lze říci, že na rozdíl od Adorna nachází Kogawa v „kutilské“ intervenci nečekaný potenciál, který může změnit silně konzumní a jednosměrný charakter rozhlasu. Příkladem intervence, která má potenciál proměnit výše nastíněnou situaci, je podle Kogawy právě stavba malých rozhlasových FM vysílačů. Ty mají být pragmatickou odpovědí na problémy, které vycházejí z odcizující moci technologie a jednostrannosti rozhlasového formátu. Ačkoli jsou rádiové vlny přírodním zdrojem, na rozdíl od jiných přírodních zdrojů, které se nacházejí na konkrétním místě, se radiové vlny vyskytují „v̌sude kolem nás.“ Přesto jsou vyhrazeny profesionálním inženýrům, sofistikovaným zařízením a jsou chráněné přísnými regulacemi telekomunikačních úřadů. Stačí ale jen pár pohybů rukou a může být hotový malý pirátský vysílač, který dokáže narušit bariéru mezi kutilskou ruční prací a odosobněnou profesionální technikou.

4 K problematice rozhlasového poslechu hudby viz též ADORNO, Theodor, Úvod do sociologie hudby, 2014, Praha: Filosofia.

5 ADORNO, Theodor - HORKHEIMER, MAX, Dialektika osvícenství, 2009, Praha: OIKOYMENH, s. 124.

6 KOGAWA, Tetsuo, Adorno's Strategy of „Hibernation“, TELOS, č. 46, 1980-81 [cit. 2017-08-31]. Dostupné z: http://anarchy.translocal.jp/non-japanese/adorno.html.

7 HARING Kristen, Ham Radio's Technical Culture, Cambridge, Massachusetts: The MIT Press, s. 21. 


\section{Mikronizace rozhlasu: zpět ke znějícímu místu}

Nápad ohledně využití malých vysílačů vznikl na Kogawových seminářích po selhání radikálních studentských hnutí na konci 70 . let. ${ }^{8}$ V diskuzích s Félixem Guattarim ${ }^{9}$ se Kogawa inspiroval rozkvětem pirátských radií v tehdejší Itálii. Kogawa nalezl v tehdejším japonském zákoně o elektronických komunikacích formulaci o možnosti provozu zařízení (bezdrátové mikrofony, televizní ovládání, otvírání garáží, RC modely aj.), které „nepřekroči 15 mikrovoltů na metr ve vzdálenosti 100 metrů od vysílače. "10 Kogawa na základě této formulace formát „velké“ rozhlasové stanice podrobil „mikronizaci“ - dosah „mikronizovaných“ vysílačů může být v praxi omezen jen na oblast několika stovek nebo i jen desítek metrů. Přesto získalo hnutí spojené s těmito vysílači v Japonsku nečekanou popularitu. ${ }^{11}$

Kogawa pomocí provozu malých vysílačů navozuje situace, v nichž se zvuk zpět ke konkrétnímu znějícímu místu navrací, zatímco v tradičním rozhlasovém formátu od něj byl oddělen. Zároveň ale nejde o pouhý retrográdní krok „zpět“ - v př́ípadě využití mikrovysílačů vzniká unikátní a nová zvuková situace. Pokud tradiční rozhlasový formát „velké stanice“ umožnil hudbu vytrhnout z místa konkrétní realizace a dokázal libovolně přesouvat její „znějící místo“ bez ohledu na geografické vzdálenosti, pak praxe mikrorádií svévolně omezuje slyšitelnost na velmi malou oblast. Média podle Kogawy musí být „mikronizována"12 a i menší, lokální stanice jsou ještě příliš veliké, jelikož pouze kopírují formát velkých rozhlasových stanic, jakkoli jej naplňují lokálním obsahem. Velikost rozhlasových stanice je třeba zmenšit na samotnou hranici únosnosti. Co se může jevit jako absurdní a trochu podivínská snaha o svévolné omezování technických prostředků, může být ve výsledku kreativní taktikou, jak se vyhnout pasti postupné normalizace takových médií, jejichž zpočátku revoluční forma postupně mizí a podléhá standardizaci.

V textu New trends in Japanese popular culture Kogawa uvažuje nad tendencí malých rozhlasových stanic k pouhému kopírování formátu mainstreamových stanic. ${ }^{13}$ Kogawa vyzdvihuje aktivity takových mikro-stanic, které současně nabízí prostor k setkávání lidí.

8 KOGAWA, Tetsuo. Toward Polymorphous Radio. In Radio Rethink: Art, Sound and Transmission, AUGIATIS, Daina - LANDER, Dan (eds.). Banff: Banff Centre Press, 1990 [cit. 2017-08-31]. Dostupné z: http:// anarchy.translocal.jp/non-japanese/radiorethink.html.

9 GUATTARI, Félix, Machinic Eros, 2015, Minneapolis: Univocal, s. 17-41.

10 KOGAWA, Tetsuo, New trends in Japanese popular culture. In The Japanese trajectory: modernization and beyond, MCCORMACK, Gavan - SUGIMOTO, Yoshio (eds.). Cambridge: Cambridge University Press, 1988 [cit. 2017-08-31]. Dostupné z: http://anarchy.translocal.jp/non-japanese/popular.html

$11 \mathrm{O}$ vzniku pozoruhodných okruhů kolem scény mikro-rádia v Japonsku 80. let viz Kogawův rozhovor s Anjou Kanngieser: KOGAWA Tetsuo - KANNGIESER, Anja. A Micro-History of 'Convivial' Radio in Japan. A conversation with Tetsuo Kogawa with an introduction by Anja Kanngieser. parallax, 2013, roč. 19, č. 2, s. 85-94.

12 KOGAWA, Tetsuo - CÁB, Michael, Ruce jsou poslední ostrovy těl, A2, 2016, č. 11 [cit. 2017-08-31]. Dostupné z: https://www.advojka.cz/archiv/2016/11/ruce-jsou-posledni-ostrovy-tel

13 KOGAWA, Tetsuo. New trends in Japanese popular culture, op. cit. 
Tento druh stanic funguje jako komunita, do vysílací místnosti volně přichází různí lidé, zúčastňují se vysílání, které není podřízené přísné programové dramaturgii. Mikrofony zachycují i ruchy, které se tradiční rozhlasový provoz naopak snaží odfiltrovat, jako jsou hovory v pozadí, šustění papírů, zvuky zavírání dveří atd. ${ }^{14}$ Tento prríklad také nejlépe vystihuje svéráznou hudebnost tohoto „okrajového“ radiového formátu, na rozdíl od lokálních či stanic specializovaných na menšinové žánry. Podobné mikrorádio však radikálně popírá jednotu samotného rozhlasového vysílání, a činí předmětem zájmu i takové situace, které by byly považovány za zvukové ruchy. Experiment se zvukem se prolíná s experimentováním s radiovými vlnami a v neposlední řadě se sociálním experimentem $\mathrm{v}$ daném „studiovém“ prostoru. ${ }^{15}$

\section{Kutilské zkoumání hudebnosti malých vysílačů}

Poněkud nevyužitý potenciál scény miniaturních radiových stanic byl však zatlačen do pozadí s nástupem internetu. Kogawa se ale nijak nostalgicky neohlíží za „zlatou érou mikrorádia“ z 80. let, a ve svém pozdějším díle se zaměřuje na zkoumání specifické hudebnosti miniaturních vysílačů. Tvorbu Tetsua Kogawy je ale přesto obtížné jednoznačně označit jako tvorbu jednoznačně hudební. Ačkoli jeho radiové intervence mohou nabývat výsledné podoby organizovaného zvuku, zdá se, že po úpadku japonské mikrorádiové scény, se stává výraznou součástí jeho umělecké tvorby právě hudebnost vzájemné interakce pohybu rukou a několika vysílačů. ${ }^{16}$ Zvláštním objektem Kogawova zájmu jsou právě ruce: „poslední ostrovy“ či „minimální jednotka našich těl“:

„Pokud ruce predstavují jakousi „minimálni jednotku“ našich těl, pak jejich využití prí vysiláni dočasně vytvár̆́ vizuálni a zvukový proces, kde může vzájemně rezonovat technologie, uměni a lidská existence."17

Účastníci performancí a workshopů mohou zakusit zvláštní pocit, když před nimi za rychlého kmitání Kogawových prstů vzniká funkční prototyp vysílače. Klíčovou součást jeho performancí tvoří právě ruční stavba jednoduchého FM vysílače, jehož signál lze zachytit běžným rozhlasovým přijímačem. Kogawa umělecké performativní gesto redukuje na ruční sletování několika vysílačů a experimentování s nimi. Kogawa pečlivě zkoumá hudebnost nejjednodušších vysílačů: jednotranzistorových oscilátorů, jejichž rezonanční obvod je tvořen laditelným kondenzátorem a několika závity drátu. V nejzákladnější verzi se vysílač skládá z pouhých deseti součástek. Několik vysílačů naladěných na blízké frekvence tvoří zvláštní zvukové efekty, které umělec ovlivňuje i velmi jemnými pohyby svých rukou. Zvláštní skrumáž zvuků a interferencí nelze mít nikdy stoprocentně

14 Ibid.

15 Ibid.

16 Viz např. videozáznam performance „Inductance“ (v.160117) [cit. 2017-08-31]. Dostupné z: https://www. youtube.com/watch?v=Bv1I3haPuWU.

17 KOGAWA, Tetsuo. Radio in the Chiasme, op. cit., s. 409. 
pod kontrolou, nestabilní oscilátory pomalu ujíždějí a vytvářejí specifické rezonance. Nevýhody jednoduchého zapojení, nad kterým by se profesionální konstruktér jistě pousmál, se pro kreativní umělecké využití stávají vítanými vlastnostmi, nebot umožňují interagovat s pohyby rukou. Právě ruce tvoří zásadní objekt zájmu Kogawova interdisciplinárního díla. Jde o zkoumání funkce ruky, která zařízení dává dohromady, ale také následně ovlivňuje jeho dokonalost působením na stabilitu oscilátoru - přiblížením ruky je ovlivněna frekvence malého vysílače a v kombinaci s přijímačem vzniká jakýsi nevypočitatelný syntezátor.

Kogawa oponuje tradiční hierarchii, podle níž by měl začínající zájemce o elektroniku stavět nejprve přijímač, a až po nabytí základních dovedností stavět vysílač. Kogawa tvrdí, že „vysílání je logicky nutný předpoklad př́jmu. "18 Podobné tvrzení se může zdát dosti radikální a právě v něm se objevuje kritický komentář k pasivní roli posluchače v obvyklých rozhlasových formátech, kde je autoritativně vytyčena ostrá hranice mezi tvůrci a konzumenty, potažmo přijímačem a vysílačem.

Kogawova umělecká aktivita tak tvoří pomyslný průsečík mezi teorií médií, sound-artem, politickým aktivismem a praktickou stavbou miniaturních vysílačů. Kogawovy performance nejsou pouze praktickým návodem ke stavbě pirátského vysílače, ale též zkoumají specifickou hudebnost narychlo zhotovených vysílačů. Tetsuo Kogawa nevychází z intencionální snahy po tom vytvářet hudbu, ale spíše ze zkoumání hraničních oblastí rozhlasového média. Hudebnost zmíněných mikrorádií tkví ve využití jevů, kterým se profesionální konstruktéři vysokofrekvenční techniky snaží co nejvíce vyhnout, ale které mohou vytvářet specifické zvukové projevy. Jde nestability oscilátorů, jejich ovlivňování okolním prostředím, vzájemné zpětné vazby, intermodulace a šumy.

\section{Mikrorádio dnes?}

Co si však s výše nastíněnou taktikou mikrovysílání počít v současné době, kdy poslech klasického rozhlasu stále upadá, a to ku prospěchu digitálních formátů? Není divu, že i některé veřejnoprávní rozhlasové stanice $\mathrm{v}$ souladu $\mathrm{s}$ vy̌še nastíněným trendem svou aktivitu cílí převážně do internetové sféry. Rozhlas s rozvojem internetu utrpěl zásadní proměnu - jednostranné médium tak trochu zaostává za demokratičtějším a interaktivnějším internetem. Společně s rozvojem internetu se může zdát, že se potenciál klasického analogového rozhlasu pomalu ale jistě vyčerpal.

Přesto můžeme konstatovat, že nakažlivý koncept mikrorádií má stále schopnost šíriit se světem - důkazem je např́íklad radioartový manifest vídeňského Kunstradia. ${ }^{19}$ Ačkoli se může zdát, že s rozvojem internetu ztrácí mikrorádio svůj potenciál, objevují se rozmanité způsoby jeho využití i dnes. Hudební i politickou funkcí jednoduchých FM vysílačů v souvislosti s budoucností analogového vysílání se zabývá britská umělkyně a teoretička

18 KOGAWA, Tetsuo - CÁB, Michael. Ruce jsou poslední ostrovy těl, op. cit.

19 ADRIAN, Robert. Toward A Definition Of Radio Art [online] [cit. 2017-08-31]. Dostupné z: http://www. kunstradio.at/TEXTS/manifesto.html. 
Magz Hall. ${ }^{20}$ Pražský éter v roce 2011 oživilo mikrorádio Skutečnost svým projektem k 200. výročí narození K.H. Máchy, kdy se rozeznělo 12 miniaturních vysílačů v lokalitách spojených s výskytem tohoto romantického básníka. ${ }^{21}$ Využití podobných mikrovysílačů rozvádí také český umělec Michal Cáb v pozoruhodném textu Od Datla k Rituálu:

„Městský chodec by při toulkách ulicemi ve svém radioprïímači mohl poslouchat signály, které by tvořily jakési zvukové oázy, vybizejici $k$ zastaveni a občerstveni. Využiti takové sítě vysilačů v sobě nese dalši možnosti: od soukromého nasloucháni poezii pres společnou procházku až $k$ určité formě tiché demonstrace $^{\text {"22 }}$

Zdá se tak, že potenciál mikrorádia nebyl ani s masovým rozvojem internetu vyčerpán a podobný koncept si stále udržuje svou přitažlivost jak na zahraniční, tak i na tuzemské umělecké scéně.

\section{Bibliography}

ADRIAN, Robert. Toward A Definition Of Radio Art [online] [cit. 2017-08-31]. Dostupné z: http:// www.kunstradio.at/TEXTS/manifesto.html

ADORNO, Theodor. Úvod do sociologie hudby. Praha: Filosofia, 2014.

ADORNO, Theodor - HORKHEIMER, Max. Dialektika osvicenstvi. Praha: OIKOYMENH, 2009.

GUATTARI, Félix. Machinic Eros. Minneapolis: Univocal, 2015.

CÁB, Michal. Od Datla k Rituálu. A2, 2011, č. 10. [cit. 2017-08-31]. Dostupné z: https://www.advojka.cz/archiv/2011/10/od-datla-k-ritualu.

HALL, Magz. Radio After Radio: Redefining radio art in the light of new media technology through expanded practice [disertační práce]. London: University of the Arts London, 2015. [cit. 201708-31]. Dostupné z: https://www.academia.edu/12987163/Radio_After_Radio_Redefining_radio_art_in_the_light_of_new_media_technology_through_expanded_practice.

HARING, Kristen. Ham Radio's Technical Culture. Cambridge, Massachusetts: The MIT Press, 2015. KOGAWA, Tetsuo. Adorno's Strategy of „Hibernation“. TELOS, č. 46, 1980-81 [cit. 2017-08-31]. Dostupné z: http://anarchy.translocal.jp/non-japanese/adorno.html.

KOGAWA, Tetsuo. Beyond electronic individualism. Canadian Journal of Political and Social Theory/ Revue Canadienne de Théorie Politique et Sociale. 1984, roč. 8, č. 3. [cit. 2017-08-31]. Dostupné z: http://anarchy.translocal.jp/non-japanese/electro.html.

KOGAWA, Tetsuo. New trends in Japanese popular culture. In The Japanese trajectory: modernization and beyond. MCCORMACK, Gavan - SUGIMOTO, Yoshio (eds.). Cambridge: Cambridge

20 HALL, Magz. Radio After Radio: Redefining radio art in the light of new media technology through expanded practice, 2015 disertační práce, London: University of the Arts London [cit. 2017-08-31]. Dostupné z: https://www.academia.edu/12987163/Radio_After_Radio_Redefining_radio_art_in_the_light_of_new_media_technology_through_expanded_practice.

21 Kol. aut. Mácha - Pirátské rádio poezie [online] [cit. 2017-08-31]. Dostupné z: http://skutecnost.cz/radio.

22 CÁB, Michal. Od Datla k Rituálu. A2, 2011, č. 10. [cit. 2017-08-31]. Dostupné z: https://www.advojka.cz/ archiv/2011/10/od-datla-k-ritualu. 
University Press, 1988 [cit. 2017-08-31]. Dostupné z: http://anarchy.translocal.jp/non-japanese/popular.html.

KOGAWA, Tetsuo. Toward Polymorphous Radio. In Radio Rethink: Art, Sound and Transmission, AUGIATIS, Daina - LANDER, Dan (eds.). 1990, Banff: Banff Centre Press, [cit. 2017-08-31]. Dostupné z: http://anarchy.translocal.jp/non-japanese/radiorethink.html.

KOGAWA, Tetsuo - CÁB, Michal. Ruce jsou poslední ostrovy těl, A2, 2016, č. 11. [cit. 2017-08-31]. Dostupné z: https://www.advojka.cz/archiv/2016/11/ruce-jsou-posledni-ostrovy-tel.

KOGAWA Tetsuo - KANNGIESER, Anja. A Micro-History of 'Convivial' Radio in Japan. A conversation with Tetsuo Kogawa with an introduction by Anja Kanngieser, parallax, 2013, roč. 19, č. 2, s. 85-94.

Kol. aut., Mácha - Pirátské rádio poezie [online] [cit. 2017-08-31]. Dostupné z: http://skutecnost.cz/ radio. 